\title{
ANALISIS KEMAMPUAN BERPIKIR TINGKAT TINGGI MENURUT TEORI ANDERSON DAN KRATHWOHL
}

\author{
Nur Ahyana ${ }^{1}$ \\ Andi Alim Syahri ${ }^{2 *}$ \\ ${ }^{1,2}$ Prodi Pendidikan Matematika, Universitas Muhammadiyah Makassar, Indonesia \\ nurahyana20@gmail.com ${ }^{1)}$ \\ andialims@unismuah.ac.id ${ }^{2}$ )
}

\begin{abstract}
Abstrak
Penelitian ini bertujuan untuk mengetahui kemampuan berpikir tingkat tinggi peserta didik berdasarkan teori Anderson dan Krathwohl materi program linear pada level menganalisis, mengevaluasi dan mencipta. Jenis penelitian yang digunakan dalam penelitian ini adalah penelitian deskriptif. Kelas yang dipilih adalah kelas XI MIA 1 semester ganjil yang telah mempelajari materi program linear, kelas tersebut dipilih berdasarkan kelas yang memiliki hasil belajar yang tinggi atau aktif dan berprestasi diantara kelas XI yang lain. Subjek dalam penelitian ini berdasarkan hasil tes yang terdiri dari 2 peserta didik yang memiliki nilai tertinggi. Instumen dalam penelitian ini adalah tes kemampuan berpikir tingkat tinggi dan wawancara. Adapun teknik pemeriksaan keabsahan data pada penelitian ini dilakukan dengan menggunakan triangulasi sumber. Hasil penelitian menunjukkan bahwa subjek dapat memenuhi kemampuan berpikir tingkat tinggi dilihat dari level menganalisis, dimana subjek dapat membedakan hal-hal yang relevan, dapat mengorganisasikan informasi dan dapat menghubungakan informasi dalam suatu konsep. Pada level mengevaluasi, subjek dapat memeriksa fakta-fakta yang ada dan mengkritisi suatu hal yang kurang tepat dan pada level mencipta, subjek dapat menciptakan dan merancang langkah-langkah pemecahan masalah dan menghasilkan produk baru.
\end{abstract}

Kata Kunci: Kemampuan Berpikir Tingkat Tinggi, Teori Anderson dan Krathwohl.

\section{Pendahuluan}

Pendidikan nasional berfungsi mengembangkan kemampuan dan membentuk watak serta peradaban bangsa yang bermartabat dalam rangka mencerdaskan kehidupan bangsa. Sesuai dalam undang-undang sistem pendidikan nasional di Indonesia No. 20 tahun 2003 dinyatakan bahwa tujuan pendidikan nasional adalah mengembangkan potensi peserta didik agar menjadi manusia yang beriman dan bertakwa kepada tuhan yang maha esa, berakhlak mulia, sehat, berilmu, cakap, kreatif, mandiri dan menjadi warga negara yang demokratis serta bertanggung jawab. (Helmawati. 2019). Salah satu potensi diri peserta didik yang perlu ditingkatkan adalah kecerdasan sebagaimana tersirat dalam undang-undang tersebut. Kecerdasan peserta didik dapat ditingkatkan salah satunya dengan mengembangkan kemampuan berpikir peserta didik dalam menyelesaikan persoalan, salah satunya adalah persoalan matematis. Keterampilan berpikir merupakan salah satu kecakapan hidup yang perlu dikembangkan melalui proses pendidikan. Maka diperlukan suatu terobosan yang bisa 
memperbaiki mutu pendidikan ke arah yang lebih baik dan dapat meningkatkan kecerdasan, pengetahuan, kepribadian, akhlak mulia, serta keterampilan untuk hidup mandiri. Salah satu indikator pembelajaran bermutu adalah dapat membelajarkan peserta didik belajar secara mandiri dan mengembangkan kemampuan berpikir tingkat tinggi.

Keterampilan berpikir tingkat tinggi dibutuhkan pada masa mendatang. Kesuksesan pada abad ke-21 bergantung pada sejauh mana seorang individu mengembangkan keterampilan-keterampilan yang tepat untuk menguasai kekuatan kecepatan, kompleksitas, dan ketidakpastian yang berhubungan satu sama lain. Kompleksitas dunia semakin meningkat dan menuntut manusia untuk menganalisis setiap situasi secara logis dan memecahkan masalah secara kratif. Belajar bukan hanya aktivitas mengetahui jawaban-jawaban, belajar tidak hanya diukur dengan indeks presetasi dan nilai ujian semata, belajar bukan hanya aktivitas diatas kertas ataupun papan tulis yang diketahui orang. Belajar merupakan petualangan seumur hidup, perjalanan eksplorasi tanpa akhir untuk menciptakan pemahaman dan personal kita sendiri. Kemampuan berpikir peserta didik dapat dikembangkan melalui pemberian soal matematika yang berbasis pada kejadian nyata (kontekstual). Soal-soal kontekstual akan melatih peserta didik untuk berpikir kritis, logis, dan sistematis dalam menyelesaikan masalah yang ada di kehidupan sehari-hari. Soal-soal kontekstual mampu membiasakan peserta didik berhadapan secara langsung dengan kejadian-kejadian atau masalah-masalah nyata yang ada di lingkungan sekitar mereka. Peserta didik tidak hanya diarahkan untuk menyelesaikan contoh soal yang ada di buku, akan tetapi peserta didik juga diajarkan untuk mengaplikasikan pelajaran matematika yang didapat di sekolah dengan kejadian- kejadian yang terjadi di lingkungan sekitar, sehingga peserta didik dapat secara langsung memahami manfaat dari pelajaran yang diberikan.

Rosnawati (2009) Mengatakan bahwa ketika peserta didik berhasil menyelesaikan masalah berarti mereka telah belajar aturan baru yang lebih kompleks dariaturan-aturan yang ada sebelumnya. Aturan-aturan yang lebih kompleks inilah yang mendorong peserta didik untuk berpikir pada tingkatan berpikir yang lebih tinggi (High Order Thinking). Kemampuan berpikir tingkat tinggi merupakan suatu kemampuan berpikir yang tidak hanya membutuhkan kemampuan mengingat saja, akan tetapi membutuhkan kemampuan lain yang lebih tinggi, seperti kemampuan berpikir kreatif dan kritis. Pembelajaran matematika yang mampu melatih kemampuan berpikir tingkat tinggi peserta didik adalah pembelajaran yang dapat membuat para peserta didik untuk bergulat dengan ide-ide baru, membuat dan mempertahankan penyelesaian soal dan berpartisipasi di dalam komunitas pelajar matematika. Oleh sebab itu, pembelajaran matematika peserta didik harus didorong untuk aktif dan guru harus memiliki potensi untuk memancing peserta didik agar rasa ingin tahunya menjadi tinggi dan mengembangkan 
kemampuan berpikir tingkat tinggi dan pemahamannya sendiri.

Namun kenyataannya pembelajaran matematika di sekolah masih menggunakan pembelajaran yang kurang bisa melatih kemampuan berpikir tingkat tinggi peserta didik. Matematika selama ini menjadi momok para peserta didik yang menganggap bahwa pelajaran matematika adalah pelajaran yang sulit, penuh rumus dan penuh angka sehingga banyak peserta didik yang kurang menyukai pelajaran matematika bahkan matematika dianggap sebagai hal yang menakutkan. Padahal peserta didik yang kurang menyukai pelajaran matematika akan menyebabkan kecemasan yang membuat kesulitan dalam memahami materi yang disampaikan dan berdampak pada rendahnya prestasi belajar matematika.

Kurikulum 2013 yang saat ini diterapkan oleh pemerintah juga menuntut peserta didik untuk berpikir tingkat tinggi. Hal ini ditunjukkan dengan adanya beberapa kata kerja operasional yang menunjukkan kemampuan berpikir tingkat tinggi peserta didik di dalam kompetensi inti (KI) kurikulum 2013. Sebagaimana tercantum dalam Kemdikbud Nomor 24 Tahun 2016 tentang Kompetensi Inti dan Kompetensi Dasar Pelajaran Kurikulum 2013 pada Pendidikan Dasar dan Pendidikan Menengah bahwa kompetensi inti kelas XI SMA adalah sebagai berikut: KI.3: Memahami, menerapkan, dan menganalisis pengetahuan faktual, konseptual, prosedural, dan metakognitif berdasarkan rasa ingintahunya tentang ilmu pengetahuan, teknologi, seni, budaya, dan humaniora dengan wawasan kemanusiaan, kebangsaan, kenegaraan, dan peradaban terkait penyebab fenomena dan kejadian, serta menerapkan pengetahuan prosedural pada bidang kajian yang spesifik sesuai dengan bakat dan minatnya untuk memecahkan masalah. Dan KI.4: Mengolah, menalar, dan menyaji dalam ranah konkret dan ranah abstrak terkait dengan pengembangan dari yang dipelajarinya di sekolah secara mandiri, bertindak secara efektif dan kreatif, serta mampu menggunakan metoda sesuai kaidah keilmuan. (Kemdikbud, 2016) Kata "menganalisis" pada KI.3 dan Kata "menyaji” pada KI 4 menunjukkan bahwa dalam kurikulum 2013 peserta didik dituntut untuk memiliki kemampuan bernalar yang merupakan kemampuan berpikir tingkat tinggi.

Benjamin S. Bloom (Wicasari, 2016) yang terkenal dengan teori berpikirnya mengutarakan beberapa tingkatan berpikir yaitu pengetahuan, pemahaman, penerapan, analisis, sintesis, dan evaluasi. Selama bertahun-tahun, tingkatan kognitif tersebut sering dijadikan sebagai tangga yang menuntun para guru untuk mendorong para peserta didik untuk mencapai level yang lebih tinggi. Namun seiring perkembangan jaman dan untuk menyesuaikan dengan tujuan pembelajaran pada era saat ini maka Krathwohl dan Anderson yang merupakan murid dari Bloom mencoba untuk merevisi tingkatan berpikir dari Bloom yang terkenal dengan sebutan taksonomi bloom menjadi: mengingat, memahami, mengaplikasikan, menganalisis, 
mengevaluasi dan mencipta. Berbeda dengan Bloom yang menggunakan kata benda (noun) dalam tahapan berpikir, Anderson dan Krathwohl menggunakan kata kerja (verb) dalam tahapan berpikir.

Berdasarkan hasil observasi yang dilakukan masih banyak peserta didik yang belum mampu mencapai kemampuan berpikir tingkat tinggi. Dilihat dari observasi kelas dalam mengerjakan soal matematika. Dari 28 peserta didik hanya satu peserta didik yang mampu menyelesaikan soal sampai level mencipta, dan 2 peserta didik yang mampu sampai pada level mengevaluasi dan 9 peserta didik yang mampu sampai pada level menganalisis, sedangkan 16 peserta didik yang lainnya tidak menyelesaikan soal sama sekali. Pada tahap menganalisis, peserta didik dituntut untuk dapat menganalisis informasi yang masuk dan membagi-bagi suatu informasi kedalam bagian yang lebih kecil. Pada tahap mengevaluasi, peserta didik dituntut mampu menerima atau menolak suatu pernyataan berdasarkan kriteria yang telah ditetapkan. Tahap mengevaluasi pada observasi ini ditunjukan ketika peserta didik dapat membedakan kasus maksimal dan minimal. Pada tahap mencipta, peseta didik harus mampu membuat generalisasi suatu ide atau cara pandang terhadap sesuatu. Pada observasi ini dapat ditunjukan ketika peserta didik mampu merancang gagasan atau ide baru untuk menyelesaikan suatu persoalan/masalah.

Melalui berpikir kreatif dan kritis memungkin peserta didik untuk mempelajari masalah secara sistematis, menghadapi berjuta tantangan dengan cara terorganisasi, merumuskan pertanyaan inovatif dan merancang solusi. Berpikir kritis dan kreatif bagai dua sisi mata uang, kegiatan ini memberikan kesempatan untuk mempraktikkan pemikiran dalam tingkatan yang lebih tinggi dalam proses pembelajaran.

Menurut Adi W. Gunawan (David: 2014) menyatakan indikator yang digunakan sebagai ciri dari kemampuan berpikir tingkat tinggi dapat diamati dalam aspek kognitif peserta didik yaitu tingkat analisis, sintesis, dan evaluasi, sebagai berikut:

1. Analisis adalah kemampuan untuk memecahkan atau menguraikan suatu materi atau informasi menjadi komponen-komponen yang lebih kecil sehingga mudah dipahami. Indikatornya adalah:
a) Membuat pertanyaan-pertanyaan tentang topik
b) Melakukan penyelidikan tentang topik
c) Membuat bagan untuk menjelaskan topik

2. Sintesis adalah kemampuan untuk menyatukan bagian-bagian atau komponen menjadi suatu bentuk yang lengkap dan unik. Indikataronya adalah:

a) Membuat model unutuk menjelaskan ide baru 
b) Merancang sebuah rencana tentang topik

c) Membuat hipotesis tentang topik

3. Evaluasi adalah kemampuan untuk menetukan nilai suatu materi untuk tujuan tertentu. Indikatornya adalah:

a) Melakukan diskusi mengenai topik

b) Menyiapkan sebuah studi kasus untuk menjelaskan pemikiran mengenai topik

c) Membuat sebuah kesimpulan umum tentang topik

Bloom menggolongkan enam tingkatan pada ranah koognitif. Enam tingkatan tersebut yaitu pengetahuan, pemahaman, penerapan, analisis, sintesis dan penilaian. Dalam menghadapi abad ke-21, Lorin Anderson dan David Krathwohl yang merupakan murid Benjamin Bloom memperbaiki struktur ranah kognitif. Perbaikan penting yang dikemukakan Anderson dan Krathwohl adalah perubahan dari kata benda ke kata kerja. Perubahan ini disebabkan taksonomi perlu mencerminkan berbagai bentuk atau cara berpikir dalam suatu proses yang aktif. Dengan demikian, penggunaan kata kerja lebih sesuai dari pada kata benda.

Tabel 1. Perbedaan Taksonomi Bloom dan Anderson

\begin{tabular}{cc}
\hline Taksonomi Bloom & Taksonomi Revisi \\
& Anderson and Krathwohl \\
\hline Pengetahuan & Mengingat \\
Pemahaman & Memahami \\
Penerapan & Menerapkan \\
Analisis & Menganalisis \\
Sintesis & Mengevaluasi \\
Evaluasi & Mencipta \\
\hline
\end{tabular}

Sumber: Anderson \& Krathwohl (2017)

Keenam kategori diubah menjadi kata kerja, kemudian beberapa sub kategori juga mengalami perbaikan dan perubahan. Pengetahuan merupakan hasil berpikir bukan cara berpikir, sehingga di perbaiki menjadi mengingat yang menunjukan suatu proses tingkat awal. Menilai ditempatkan setelah menganalisis kemudian ditempatkan mencipta sebagai pengganti sintesis. Hal ini dilakukan untuk menempatkan tingkatan dari proses berpikir yang paling mudah ke proses penciptaan yang lebih rumit dan sulit. Anderson dan Krathwohl menelaah taksonomi ini agar lebih terkait dengan teori belajar yang relevan saat ini.Kategori dalam dimensi proses kognitif antara lain: (Andeson dan Krathwohl, 2017)

\section{Metode Penelitian}

Jenis penelitian yang digunakan dalam penelitian ini adalah penelitian deskriptif kualitatif. Penelitian ini dilakukan secara bertahap, adapun waktu yang digunakan ada 3 tahapan 
yaitu tahap persiapan, tahap pelaksanaan, dan tahap penyelesaian. Lokasi penelitian ini berada di SMA Negeri 18 Bone. Pengambilan data akan dilaksanakan di kelas XI SMANegeri 18 Bone. Subjek dalam penelitian ini sebanyak 2 orang siswa dengan nilai tertinggi dari hasil tes sebelumnya. Instrumen yang digunakan dalam penelitian ini terdiri dari instrumen utama dan instrumen pendukung. Instrumen utama adalah peneliti itu sendiri atau human instrumen, sedangkan instrumen pendukung, yaitu: Tes dan wawancara. Dalam penelitian ini untuk mengecek keabsahan data digunakan triangulasi. Triangulasi adalah teknik pemeriksaan keabsahan data yang memanfaatkan sesuatu yang lain diluar data itu untuk keperluan pengecekan atau sebagai perbandingan terhadap data itu. Teknik triangulasi yang digunakan adalah triangulasi sumber.

\section{Hasil dan Pembahasan}

Adapun analisis data tes dan wawancara kemampuan berpikir tingkat tinggi peserta didik materi program linear berdasarkan teori Anderson dan Krathwohl sebagai berikut.

\section{Kemampuan Berpikir Tingkat Tinggi Tahap Menganalisis}

1. Paparan data tes dan wawancara S1 saat menyelesaikan soal kemampuan berpikir tingkat tinggi materi program linear tahap menganalisis

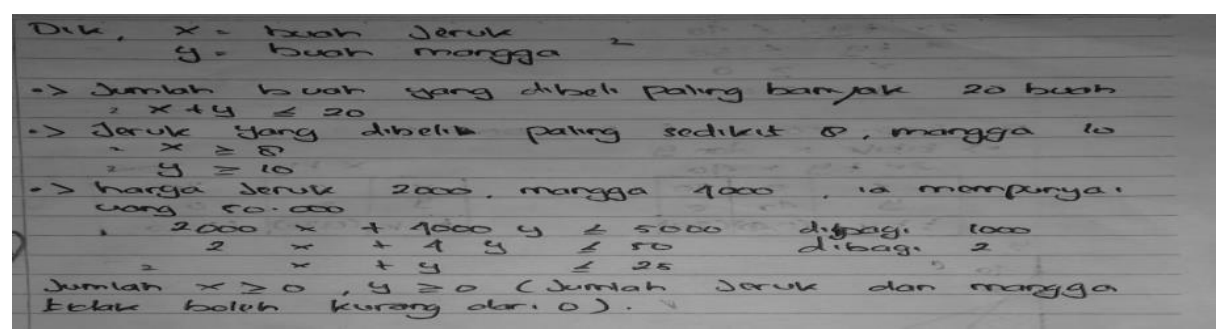

Gambar 1. Jawaban S1 Level Menganalisis

2. Paparan data tes dan wawancara S2 saat menyelesaikan soal kemampuan berpikir tingkat tinggi materi program linear tahap menganalisis

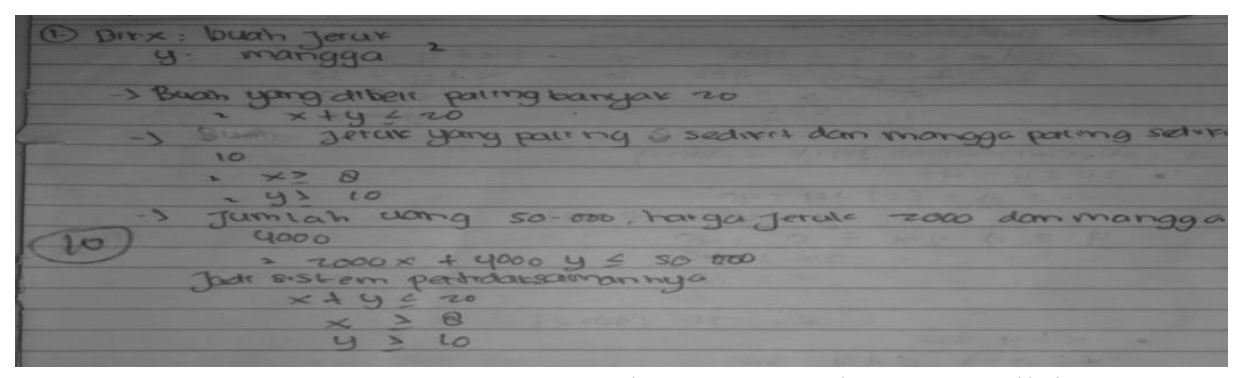

Gambar 2. Jawaban S2 Level Menganalisis

Tabel 2. Paparan Data Kemampuan Berpikir Tingkat Tinggi Tahap Menganalisis

S1 S2

S1 mampu mengidentifikasi informasi, S2 mampu menyusun informasi yang bagian yang ditanyakan dan mampu diperoleh pada sumber, menentukan 


\begin{tabular}{lll}
\hline membuat model matematika dari soal & penyelesaian dengan menganalisis \\
tersebut. S1 juga mampu merangkai & informasi yang diketahui untuk membuat \\
komponen-komponen yang ada pada & model matematikanya. S2 dapat \\
suatu konsep yaitu Dapat & menghubungkan beberapa bagian yang \\
menyimpulkan tanda pertidaksamaan & ada dalam satu konsep yaitu menentukan \\
yang digunakan berdasarkan apa yang & tanda pertidaksamaan yang akan \\
diketahui dan ditanyakan & digunakan berdasarkan apa yang diketahui \\
& dan ditanyakan \\
\hline
\end{tabular}

Dari jawaban S1 pada gambar 1, dengan nomor soal “1”. Dalam menganalisis S1 betulbetul memahami setiap komponen yang terbentuk pada saat pemecahan masalah program linear. S1 mampu membentuk model matematika dengan tepat dan memahami maksud dari setiap elemen pada model matematika tersebut. Dalam pemecahan masalah S1 dapat menggunakan kemampuan menganalisisnya dengan baik. Kemampuan berpikir tingkat tinggi S1 dalam menganalisis didahului dengan kemampuan mengidentifikasi hal-hal diketahui dan ditanyakan yaitu menentukan model matematika dalam soal tersebut. S1 memulai menyusun suatu rencana penyelesaian dengan menganalisis informasi yaitu dengan cara menentukan $x=$ jeruk dan $y=$ mangga, selanjutnya menentukan jumlah jeruk dan mangga yang harus dibeli. S1 mampumerangkai komponen-komponen penting dalam suatu konsep yaitu S1 dapat menyimpulkan tanda pertidaksamaan yang akan digunakan berdasarkan apa yang diketahui dan ditanyakan. Sesuai penjelasan kemampuan berpikir tingkat tinggi pada subjek dapat menggunakan kemampuan menganalisis. Pada indikator kemampuan berpikir tingkat tinggi tahap menganalisis peserta didik mampu membedakan hal-hal yang penting dan tidak penting, menyusun informasi yang diperoleh pada sumber dan mampu menghubungkan beberapa bagian pada satu konsep. Hasil penelitian menunjukkan S1 sudah memenuhi indikator kemampuan berpikir tingkat tinggi tahap menganalisis karena S1 dapat menguraikan informasi kedalam beberapa bagian.

\section{Kemampuan Berpikir Tingkat Tinggi Tahap Mengevaluasi}

1. Paparan data tes dan wawancara S1 saat menyelesaikan soal kemampuan berpikir tingkat tinggi materi program linear tahap mengevaluasi

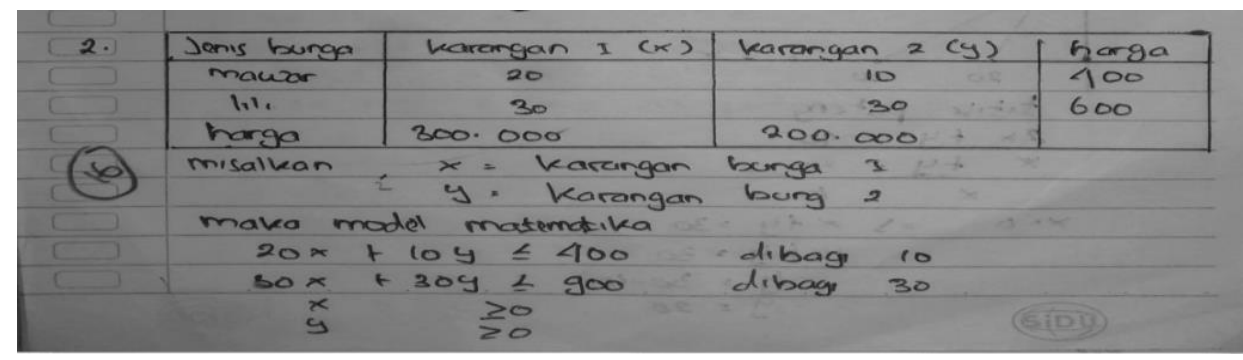

Gambar 3. Jawaban S1 Level Mengevaluasi 
2. Paparan data tes dan wawancara S2 saat menyelesaikan soal kemampuan berpikir tingkat tinggi materi program linear tahap mengevaluasi

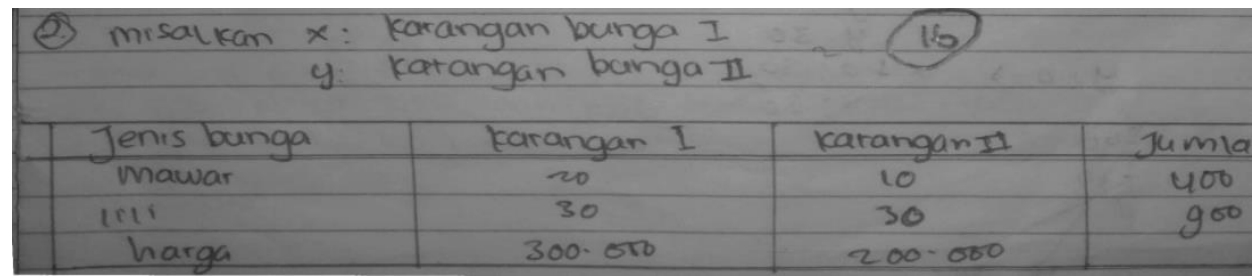

Gambar 4. Jawaban S2 Level Mengevaluasi

Tabel 3. Paparan Data Kemampuan Berpikir Tingkat Tinggi Level Mengevaluasi

\begin{tabular}{lll}
\hline S1 & \multicolumn{1}{c}{ S2 } \\
\hline S1 mampu memeriksa fakta-fakta & S2 dapat menggunakan keterampilan \\
yang ada, memahami masalah dan & mengevaluasinya, meskipun mengalami sedikit \\
mengidentifikasi bagian yang & kendala dalam mengidentifikasi hal-hal yang \\
ditanyakan dari soal. S1 mampu & diketahui. S2 dapat mengatasi masalah tersebut \\
menilai hal-hal tidak pada & dengan cara memahami/membaca kembali soal, \\
tempatnya atau kurang tepat, dengan & memeriksa fakta-fakta yang ada, \\
kata lain mampu mengenali & mengidentifikasi bagian yang ditanyakan pada \\
pernyataan yang benar yang salah. & soal. S2 dapat mengkritisi suatu hal atau tidak \\
& pada tempatnya, mampu mengenali pernyataan \\
& yang benar dan salah \\
\hline
\end{tabular}

Dari jawaban S1 pada gambar 3 dengan nomor soal "2". Dalam pemecahan masalah program linear S1 terlihat dapat melakukan kemampuan mengevaluasi dengan baik dan tepat. Dalam mengevaluasi S1 melibatkan keterampilan mengevaluasi mulai pada tahap merencanakan penyelesaian. Selain itu, dalam mengevaluasi pada indikator mengkritis suatu hal yang kurang tepat yaitu menerima atau menolak pernyataan dari peneliti, S1 melibatkan kemampuan berpikirnya dengan mengenali dan menjelaskan maksud setiap elemen dan hubungannya. Pada tahap perencanaan S1 dapat memahami masalah, mengidentifikasi hal yang ditanyakan dari soal yang diberikan yaitu berapa jumlah karangan bunga yang harus disediakan. Selanjutnya, memisalkan x dan y dan menentukan nilai pada titik-titik x dan y. Menghubungkan titik-titik tersebut sehingga menghasilkan suatu grafik himpunan penyelesaian, menentukan titik potong dengan cara eliminasi dan substitusi. Kemudian titik-titik pada daerah penyelesaian di substitusikan kefungsi tujuan yaitu $300.000 x+200.000 y$. S1 mampu memberikan suatu penilaian yaitu mampu menentukan karangan bunga yang harus disediakan untuk mendapat pendapat maksimum yaitu 10 karangan bunga 1 dan 20 karangan bunga 2 .

Sesuai penjelasan kemampuan berpikir tingkat tinggi tahap mengevaluasi pada subjek. S1 dapat menggunakan kemampuan mengevaluasinya dengan baik dilihat dari S1 dapat memahami indikator mengevaluasi yaitu mampu memeriksa fakta-fakta yang ada dan menilai 
hal-hal yang kurang tepat.

\section{Kemampuan Berpikir Tingkat Tinggi Tahap Mencipta}

1. Paparan hasil tes dan wawancara S1 saat menyelesaikan soal kemampuan berpikir tingkat tinggi materi program linear tahap mencipta

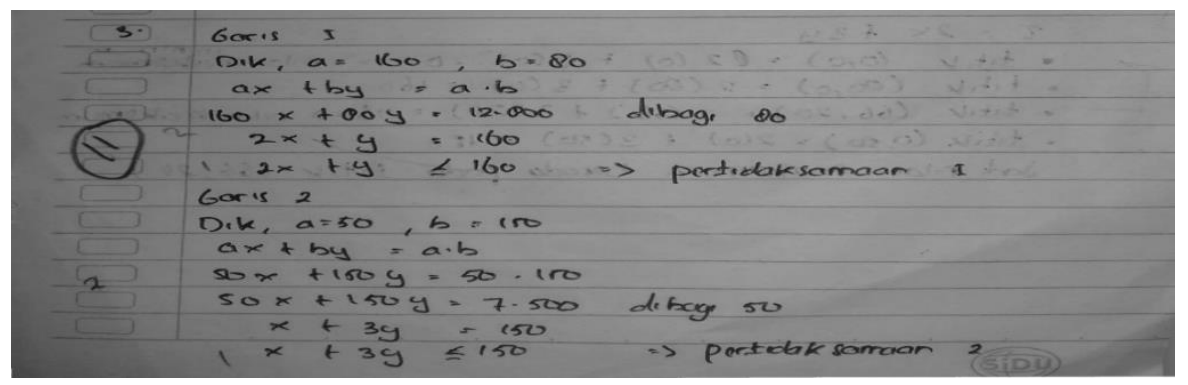

Gambar 5. Jawaban S1 Level Mencipta

2. Paparan hasil tes dan wawancara S2 saat menyelesaikan soal kemampuan berpikir tingkat tinggi materi program linear tahap mencipta

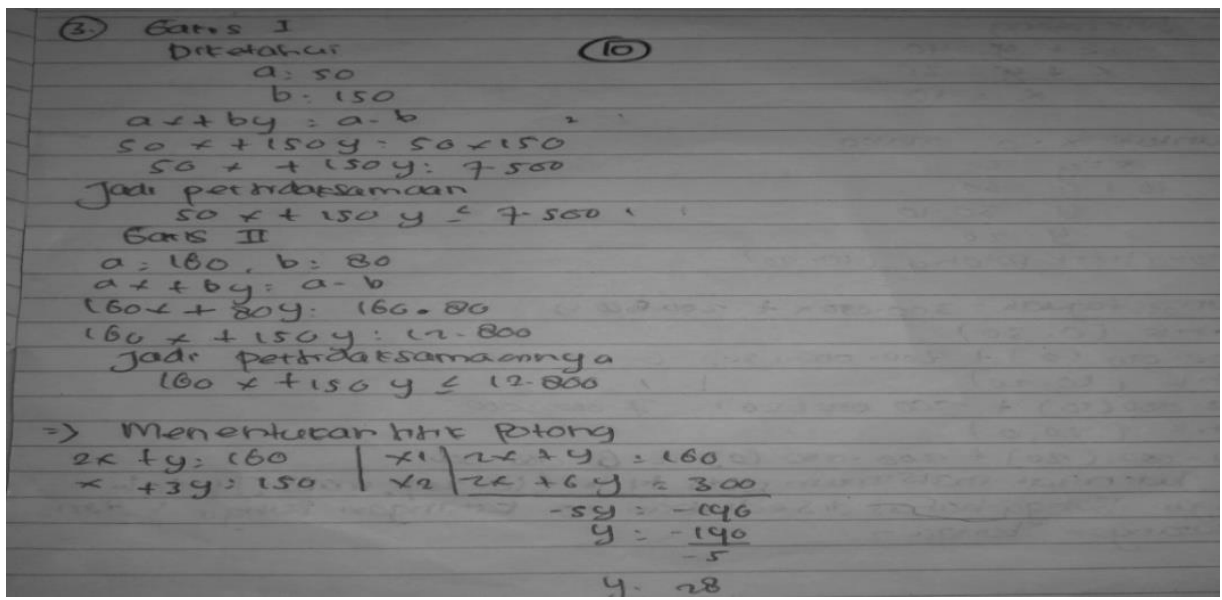

Gambar 6. Jawaban S2 Level Mencipta

Tabel 4. Paparan Data Kemampuan Berpikir Tingkat Tinggi TahapMencipta

\begin{tabular}{|c|c|}
\hline S1 & S2 \\
\hline $\begin{array}{l}\text { S1 mampu mengidentifikasi bagian } \\
\text { yang ditanyakan. S1 mampu } \\
\text { merancang dan menjelaskan kembali } \\
\text { langkah-langkah pemecahan masalah } \\
\text { yaitu menentukan suatu } \\
\text { pertidaksamaan dengan suatu rumus. } \\
\text { Menghasilkan suatu produk baru } \\
\text { yaitu menentukan suatu bentuk } \\
\text { pertidaksamaan } \\
\text { menggunakan rumus yang berbeda, } \\
\text { dengan hasil yang sama atau } \\
\text { pertidaksamaan yang sama. }\end{array}$ & $\begin{array}{l}\text { S2 mampu mengidentifikasi bagian yang } \\
\text { diketahui dan ditanyakan. S2 mampu } \\
\text { merancang dan menjelaskan kembali } \\
\text { langkah-langkah pemecahan masalah yaitu } \\
\text { menentukan suatu pertidaksamaan dengan } \\
\text { menggunakan suatu rumus. S2 juga mampu } \\
\text { menghasilkan pertidaksamaan dengan } \\
\text { rumus yang berbeda namun menghasilkan } \\
\text { hasil yang sama atau pertidaksamaan yang } \\
\text { sama. }\end{array}$ \\
\hline
\end{tabular}

Dari jawaban S1 pada gambar 5 dengan nomor soal "3". Dalam pemecahan masalah 
program linear terlihat S1 dapat menggunakan keterampilan menciptanya dengan baik. S1 mampu mengindetifikasi hal yang diketahui dan ditanyakan kan yaitu menentukan nilai pertidaksamaannya dan nilai maksimumnya. S1 dapat dapat merancang penyelesaiannya sendiri, menentukan suatu pertidaksamaan dengan menggunakan rumus $a x+b y=a b$. Selanjutnya menghubungkan tanda pertidaksamaan yang akan digunakan berdasarkan apa yang diketahui. Menentukan titik potong kemudian substitusikan titik-titik dari daerah penyelesaian kedalam fungsi tujuan yang telah ditentukan. S1 dapat menghasilkan produk baru yaitu menentukan suatu bentuk pertidaksamaan dengan menggunakan rumus yang berbeda dengan sebelumnya yaitu $\frac{x-x 1}{x 2-x 1}=\frac{y-y 1}{y 2-y 1}$ dengan mendapatkan hasil atau pertidakasamaan yang sama. Sesuai penjelasan kemampuan berpikir tingkat tinggi pada subjek, S1 dapat memenuhi indikator mencipta dengan baik dilihat dari S1dapat memenuhi indikator kemampuan berpikir tingkat tinggi pada level mencipta yaitu mampu merumuskan suatu pendapat dengan kriteriakriteria tertentu, mampu merancang suatu penyelesaian masalah dan dapat menciptakan suatu hal yang baru.

Dari hasil analisis data menujukkan bahwa subjek telah memenuhi kemampuan berpikir tingkat tinggi, dilihat pada subjek telah mampu memenuhi ketiga indikator . Pada level menganalisis subjek telah mampu membagi-bagi suatu informasi jadi bagian kecil dan menghubungkan sesuai dengan pola atau hubungannya. Pada level mengevaluasi, subjek telah mampu mengidentifikasi suatu masalah dan menilai suatu hal yang tidak tepat. Dan level mencipta, subjek telah mampu merumuskan, merencanakan suatu penyelesaiaan dan menghasilkan suatu produk baru atau menemukan beberapa solusi dalam penyelesaian masalah.

Pada saat penyelesaian masalah pada level menganalisis pada soal nomor 1 , subjek 1 dapat menggunakan kemampuan menganalisisnya dengan baik. S1 mampu mengidentifikasi bagian yang diketahui dan ditanyakan, mampu membuat model matematika dari soal tersebut. S1 mampu mendeskripsikan informasi yang ada, menentukan penyelesaian dengan menganalisis informasi yang diketahui untuk membuat model matematikanya. Sesuai dengan teori Anderson dan Krathwohl, dimana menganalisis ialah membagi materi menjadi bagian penyusunnya dan menentukan hubungan antar bagian tersebut. Dari hasil penelitian subjek dapat dikatakan memenuhi tahap menganalisis, dilihat dari subjek dapat menguraikan informasi kedalam beberapa bagian.

Pada saat penyelesaian masalah pada level mengevaluasi pada soal nomor 2, subjek dapat menggunakan kemampuan mengevaluasinya. S1 mampu memeriksa fakta-fakta yang ada, memahami masalah dan mengidentifikasi bagian yang ditanyakan dari soal yang diberikan. 
S1 dapat menilaihal-hal yang dirasa tidak tepat, dengan kata lain mampu mengenali pernyataan benar dan salah. Sesuai dengan teori Anderson dan Krathwohl, mengevaluasi ialah menariksuatu kesimpulan sesuai dengan kriteria tertentu. Dari hasil penelitian subjek dapat dikatakan memenuhi tahap mengevaluasi, dilihat dari subjek mampu memeriksa dan mengkritisi suatu informasi yaitu menerima atau menolak pernyataan dari peneliti dengan mengenali dan menjelaskan maksud setiap elemen dan hubungannya.

Pada saat penyelesaian masalah pada level mencipta pada soal nomor 3, subjek dapat menggunakan kemampuan menciptanya. S1 mampu mengidentifikasi bagian yang ditanyakan yaitu menentukan pertidaksamaan dan nilai maksimum, mampu merancang langkah-langkah pemecahan masalah dan Menghasilkan suatu produk baru yaitu menentukan suatu bentuk pertidaksamaan dengan menggunakan dua rumus yang berbeda dengan hasil yang sama atau pertidaksamaan yang sama.Sesuai dengan teori Anderson dan Krathwohl, mencipta ialah menyusun elemen-elemen sehingga membentuk sesuatu hal yang baru. Dari hasil penelitian subjek dapat dikatakan memenuhi kemampuan tahap mencipta, dilihat dari kedua subjek dapat menemukan atau memikirkan beberapa solusi dalam penyelesaian masalah.

\section{Kesimpulan dan Saran}

Berdasarkan hasil analisis data, maka kesimpulan adalah Subjek memenuhi indikator level menganalisis dilihat dari subjek mampu memisahkan bagian yang penting dari yang tidak penting, mengidentifikasi elemen-elemen dari beberapa sumber dan mampu merangkai elemenelemen dalam satu konsep. Subjek telah memenuhi indikator level mengevaluasi dilihat dari subjek dapat memeriksa dan menilai hal-hal yang tidak tepat atau bukan pada tempatnya. Subjek telah memenuhi indikator level mencipta dilihat dari subjek mampu membuat pilihan atau hipotesis yang sesuai dengan kriteria, mampu merancang penyelesaian masalah dan menemukan beberapa solusi.

\section{DAFTAR PUSTAKA}

Ambar Risqi Firdausa (2019) pengembangan instrumen tes high order thinking skils (HOST) boga dasar untuk peserta didik SMK program keahlian tata boga.

Anderson,Krathwohl. Pembelajaran, Pengajaran, Dan Asesmen Revisi Taksonomi Pendidikan Bloom.Terjemahan oleh Agung Prihantoro. 2017. Yogyakarta: Pustaka Belajar.

Ardhana, T. (2017). Keterampilan Berpikir Peserta didik dalam Menyelesaikan Soal Garis dan Sudut Berdasarkan Taksonomi Bloom Revisi. Skripsi. Surakarta: Unismuh Surakarta. 
Djadir. dkk. (2017). Sumber Belajar Penunjang PLPG 2017 Mata Pelajaran/Paket Keahlian Matematika Bab VII Program Linear. Online (https://www.usd.ac.id/fakultas/pendidikan/f1l3/PLPG2017/Download/materi/matematik a/BAB-7-PROGRAM-LINEAR.pdf, 03 februari 2020)

Ekafitria Bahar, Erni dkk. (2020). Analisis Kemampuan Matematis dalam Menyelesaikan Soal PISA (Programme For International Student Assessment) Pada Konten Kuantitas. Online. (http://ejournal.unkhair.ac.id/index.php/deltapi/article/view/2327)

Helmawati. (2019). Pembelajaran dan Penilaian Berbasis HOTS. Bandung: Remaja Rosdakarya.

Purbaningrum, K. A. (2017). Kemampuan Berpikir Tingkat Tinggi Peserta didik dalam Pemecahan Masalah Matematika Ditinjau dari Gaya Belajar. JPPM Vol. 10 No. 2, 40-49.

Rosnawati. 2009. Enam Tahapan Aktivitas dalamPembelajaran untuk Mendayagunakan Berpikir Tingkat Tinggi Peserta didik. Jurnal Edukasi, 1.

Sudianto Manullang, dkk. (2017). Matematika SMA/MA/SMK/MA Kelas XI. Jakarta: Kementerian Pendidikan dan Kebudayaan.

Sugiyono. (2018). Metode Penelitian Kuantitatif Kualitatif Dan R\&D. Bandung:Alfabeta.

Wicasari, dkk, (2016). Analisis Kemampuan Berpikir Peserta didik Dalam Menyelesaikan Permasalahan Matematika Yang Berorientasi Pada Hots. Prosiding Seminar Nasional Reforming Pedagogy 2016 